\title{
Pengaruh Model Think Talk Write Berbantuan Media Audio Visual Terhadap Keterampilan Menulis Siswa
}

\author{
Made Desimyari ${ }^{1}$, I. B. Surya Manuaba ${ }^{2}$ \\ 1,2 Jurusan Pendidikan Guru Sekolah Dasar, FIP Universitas Pendidikan Ganesha \\ e-mail: madedesimyari96@gmail.com¹, idabagussurya.manuaba@undiksha.ac.id ${ }^{2}$
}

\begin{abstract}
Abstrak
Penelitian ini bertujuan untuk mengetahui pengaruh model pembelajaran think talk write berbantuan media audio visual terhadap keterampilan menulis siswa kelas III SDN Gugus VIII I Gusti Ketut Pudja tahun ajaran 2017/2018. Jenis penelitian yang digunakan adalah eksperimen semu dengan desain penelitian non equivalent control group design. Populasi penelitian ini adalah siswa kelas III di SDN Gugus VIII I Gusti Ketut Pudja tahun ajaran 2017/2018. Sampel ditentukan dengan teknik random sampling. Sampel penelitian ini adalah siswa kelas III SDN 5 Panjer sebagai kelompok eksperimen dan siswa kelas III SDN 3 Renon sebagai kelompok kontrol. Data keterampilan menulis siswa dikumpulkan dengan instrumen tes berbentuk uraian. Teknik analisis yang digunakan untuk menganalisis data dalam penelitian adalah teknik analisis statistik inferensial. Berdasarkan hasil analisis data, diperoleh bahwa $t_{\text {hitung }}=5,025$ dan pada taraf signifikansi $5 \%$ dengan $\mathrm{dk}=(44-46)-2=88$ diperoleh $t_{\text {tabel }}=2,000$. Berdasarkan kriteria pengujian $t_{\text {hitung }}=5,025>t_{\text {tabel }}=2,000$, dan rata-rata $(\bar{X})$ hitung, diketahui bahwa $\bar{X}_{\text {eksperimen }}$ $(73,32)>\bar{X}_{\text {kontrol }}(59,50)$. Karena $t_{\text {hitung }}>t_{\text {tabel }}$, maka $H_{0}$ ditolak yang menyatakan tidak terdapat pengaruh model pembelajaran think talk write berbantuan media audio visual terhadap keterampilan menulis siswa kelas III SDN Gugus VIII I Gusti Ketut Pudja tahun ajaran 2017/2018. Sedangkan $\mathrm{H}_{\mathrm{a}}$ dierima yang menyatakan terdapat pengaruh model pembelajaran think talk write berbantuan media audio visual terhadap keterampilan menulis siswa kelas III SDN Gugus VIII I Gusti Ketut Pudja tahun ajaran 2017/2018. Dengan demikian dapat disimpulkan bahwa model pembelajaran think talk write berbantuan media audio visual berpengaruh terhadap keterampilan menulis siswa kelas III SDN Gugus VIII I Gusti Ketut Pudja tahun ajaran 2017/2018.
\end{abstract}

Kata Kunci: think talk write, audio visual, keterampilan menulis.

\begin{abstract}
The purposed of this researched was to know the effect of learning-based think talk write model with audio visual media on the writing skill of class III student in SDN Gugus VIII I Gusti Ketut Pudja academic year 2017/2018. The type of this researched was a quasi experiment with non equivalent control group design. The population of this researched was the third grade students in SDN Gugus VIII I Gusti Ketut Pudja academic year 2017/2018. The sample is determined by random sampling technique. The sample of this research is class III student of SDN 5 Panjer as experiment group and student of class III SDN 3 Renon as control group. Writing skill students were collected with a test instrument in the essay form. The analysis technique used inferential statistical analysis. Based on the result of data analysis, it was found that $t_{\text {count }}=5,025$ and at significance level $5 \%(0,05)$ with $\mathrm{dk}=(44-46)-2=88$ obtained $t_{\text {table }}=$ 2,000 . Based on theses $t_{\text {count }}=5,025>t_{\text {table }}(\alpha=0,05)=2,000$, and average $(\bar{X})$ count, it was known that $\bar{X}_{\text {experiment }}(73,32)>\bar{X}_{\text {control }}(59,50)$. Because $t_{\text {count }}>t_{\text {table }}$, then $H_{0}$ which states there was no effected of think talk write learning model assisted by audio visual media to the writing skill of class III student of SDN Gugus VIII I Gusti Ketut Pudja academic year 2017/2018 rejected and $\mathrm{H}_{\mathrm{a}}$ which stated there was effect of learning model of think talk write with audio visual media toward writing skill of class III student of SDN Gugus VIII I Gusti Ketut Pudja academic year 2017/2018 accepted. That it can be concluded that the learning model of think talk write assisted audio visual media have an effect on writing skill of class III student of SDN Gugus VIII I Gusti Ketut Pudja academic year 2017/2018.
\end{abstract}

Keywords: think talk write, audio visual, writing skills. 


\section{Pendahuluan}

Pendidikan merupakan sarana utama pembentukan generasi penerus bangsa. Semakin maju kualitas pendidikan, maka semakin maju pula negara tersebut [1]. Rendahnya kualitas pendidikan utamanya hasil belajar siswa saat ini masih belum dapat terselesaikan dengan baik. Salah satu tujuan pendidikan adalah menyelenggarakan proses belajar mengajar. Belajar dan mengajar merupakan dua konsep yang tidak bisa dipisahkan satu sama lain (Yanuarta ,2014).

Di era globalisi ini pendidikan sebagai salah satu aspek dalam meningkatkan kualitas sumber daya manusia yang terus dibenahi serta dikembangkan. Pendidikan sebagai suatu wadah pertumbuhan guna mengembangkan potensi anak yang tersembunyi. Tanpa adanya pendidikan, manusia tidak akan mengetahui berbagai macam ilmu pengetahuan. Pendidikan sangatlah penting bagi manusia, karena dengan adanya pendidikan, kemampuan berpikir manusia akan semakin meningkatkan pengetahuan oleh karena itu pendidikan manusia akan lebih mudah untuk mendapatkan pekerjaan yang nantinya dipergunakan dalam melanjutkan kehidupannya.

Hasabullah (2008:1) menyatakan bahwa, dalam arti sederhana pendidikan

sering diartikan sebagai usaha manusia untuk membina kepribadiannya sesuai dengan nilainilai di dalam masyarakat dan kebudayaan. Dalam pengembangannya, istilah pendidikan atau paedagogie berarti bimbingan atau pertolongan yang diberikan dengan sengaja oleh orang dewasa agar ia menjadi dewasa. Oleh karena itu, masalah yang dihadapi dalam dunia pendidikan adalah masalah lemahnya proses pembelajaran. Maka manusia diharuskan untuk belajar. Menurut Susanto (2015:4), belajar adalah "suatu aktivitas yang dilakukan seseorang dengan sengaja dalam keadaan sadar untuk memperoleh suatu konsep, pemahaman, atau pengetahuan baru sehingga memungkinkan seseorang terjadinya perubahan perilaku yang relatif tetap baik dalam berfikir, merasa, maupun dalam bertindak".

Tujuan pembelajaran akan dapat tercapai apabila terciptanya pembelajaran yang menyenangkan bagi siswa dengan menerapkan berbagai strategi, model atau metode pembelajaran yang bervariasi, sehingga dapat menumbuhkan minat dan motivasi siswa untuk belajar. Selain itu, keterampilan dalam memilih serta menerapkan media pembelajaran yang sesuai dengan materi pembelajaran yang dibelajarkan kepada siswa juga merupakan salah satu faktor yang berperan penting dalam mengoptimalkan keterampilan menulis siswa

Berdasarkan observasi yang dilakukan pada hari Rabu tanggal 17 Januari 2018 dengan guru kelas III SDN Gugus VIII I Gusti Ketut Pudja Denpasar Selatan, diketahui bahwa siswa SD masih mengalami kesulitan dalam pembelajaran bahasa Indonesia. Selain itu, masih ada siswa yang kesulitan dalam menulis, sehingga mengalami hambatan saat mengikuti proses pembelajaran. Mengulangi materi yang pernah diajarkan dan yang belum dikuasai siswa saja. Penggunaan media dalam kegiatan pembelajaran belum optimal, karena penyebab utama siswa yaitu tidak menguasai materi pembelajaran. Penerapan model pembelajaran inofatif masih belum optimal. Hal ini tentunya akan menciptakan kondisi pembelajaran yang kurang menarik dan menyenangkan, serta kurang menantang kemampuan berpikir siswa dan kurang dapat mengoptimalkan fungsi otak dalam belajar, sehingga siswa cenderung cepat merasa bosan.

Demikian pula dalam proses pembelajaran bahasa Indonesia. Pembelajaran bahasa Indonesia terdiri atas beberapa keterampilan seperti yang dipaparkan oleh Tarigan (2013:1) mengemukakan bahwa "keterampilan berbahasa mempunyai empat komponen, yaitu (1) keterampilan menyimak (listening skills), (2) keterampilan berbicara (speaking skills), (3) keterampilan membaca (reading skills), dan (4) keterampilan menulis (writing skills)". Setiap keterampilan itu sangat erat berhubungan dengan tiga keterampilan lainnya dengan cara beraneka ragam. Seperti, dalam proses pembelajaran sebelum membelajarkan keterampilan menulis, siswa menyimak materi yang disajikan guru, kemudian siswa diajak berbicara apabila terdapat hal-hal yang belum dipahami. Siswa juga membaca soal-soal yang disediakan dan hasil tugas-tugas yang diberikan di depan kelas. Siswa terlibat aktif menulis tugas-tugas kelompok maupun individu yang telah disediakan.Dari empat keterampilan yang diatas, hanya diteliti keterampilan menulis. Menurut Susanto (2015:246) menyatakan bahwa, menulis merupakan kegiatan yang paling sering dilakukan oleh setiap orang. Menulis membutuhkan keterampilan khusus yang harus dipelajari dan senantiasa dilatih. Menulis memerlukan keterampilan tambahan bahkan motivasi tambahan pula, hal ini dikarenakan menulis bukan bakat karena tidak semua orang mampu untuk menulis.

Salah satu model pembelajaran yang dapat membuat siswa terlihat aktif dan mendukung siswa dalam mengembangkan keterampilan berargumentasi baik secara lisan maupun tulisan 
adalah model kooperatif tipe Think-Talk-Write (TTW). Menurut Sugandi (2011:52) Think-TalkWrite (TTW) adalah model pembelajaran yang berusaha membangun pemikiran merefleksi, dan mengorganisasi ide, kemudian menguji ide tersebut sebelum siswa diharapkan untuk menuliskan ideide tersebut.

Sebagai salah satu keterampilan berbahasa yang berperan penting. Dalam penelitian ini menggunakan model pembelajaran Think Talk Write (TTW) berbantuan media audio visual dalam menerapkan keterampilan menulis. Menurut Huda (2016:218) "Model pembelajaran Think Talk Write adalah strategi yang memfasilitasi latihan berbahasa secara lisan dan menulis bahasa tersebut dengan lancar".

Model pembelajaran Think Talk Write (TTW) adalah sebuah pembelajaran yang dimulai dengan berpikir melalui bahan bacaan (menyimak, mengritisi, dan alternatif solusi), hasil bacaannya dikomunikasikan dengan presentasi, diskusi, dan kemudian membuat laporan hasil presentasi (Siswanto dan Ariani, 2016: 107). Model pembelajaran Think Talk Write (TTW) membangun pemikiran, merefleksi, dan mengorganisasi ide, kemudian menguji ide tersebut sebelum peserta didik diharapkan untuk menulis (Siswanto dan Ariani, 2016: 107). Langkahlangkah model Think Talk Write (TTW) (Shoimin, 2014: 212-214) adalah sebagai berikut: (1) guru membagikan LKS, (2) peserta didik membaca masalah dan membuat catatan kecil, (3) membagi siswa dalam kelompok kecil (3-5 siswa), (4) siswa berdiskusi (5) peserta didik secara individu merumuskan jawaban tertulis dengan bahasa sendiri, (6) presentasi kelompok, (7) refleksi (Ratna ,2017).

Salah satu kelebihan model TTW adalah dengan berinteraksi dan berdiskusi dengan kelompok akan melibatkan siswa secara aktif dalam belajar. Maka model TTW memang sangat efektif untuk mengoptimalkan proses pembelajaran guna meningkatkan keterampilan menulis bahasa Indonesia (Shoimin, 2014). Selain penggunaan model TTW, dalam proses pembelajaran juga dibutuhkan alat bantu pembelajaran yakni berupa media audio visual sehingga dapat menciptakan suasana belajar yang kondusif dan mendorong keberhasilan proses belajar mengajar. Sehingga dalam hal tersebut seorang guru harus bisa menggunakan model pembelajaran yang inovatif. Untuk memaksimalkan model pembelajaran TTW, juga digunakan media audio visual, memberikan kontribusi yang besar dalam pembelajaran dikelas, terutama pada muatan materi bahasa Indonesia. Kegiatan menulis deskripsi dengan think talk write akan lebih optimal apabila ditunjang dengan media pembelajaran. Peneliti memilih media visual untuk menunjang pembelajaran dengan model thik talk write. Media visual merupakan semua alat peraga yang digunakan dalam proses belajar yang bisa dinikmati lewat pancaindera mata (Asmarine ,2016).

Asyrah (2012:45) menyatakan, media audio visual adalah "jenis media yang digunakan dalam kegiatan pembelajaran dengan melibatkan pendengaran dan pengelihatan sekaligus dalam satu proses atau kegiatan".

Berdasarkan uraian tersebut, maka dilakukan penelitian dengan judul model pembelajaran TTW berbantuan media audio visual dalam keterampilan menulis bahasa Indonesia, tetapi secara empiris perlu dibuktikan melalui penelitian yang berjudul "Pengaruh Model Think Talk Write Berbantuan Media Audio Visual terhadap Keterampilan Menulis Siswa Kelas III SDN Gugus VIII I Gusti Ketut Pudja Denpasar Selatan Tahun Ajaran 2017/2018".

Karangan deskripsi adalah karangan yang menuliskan kesan panca indra agar pembaca atau pendengar dapat menikmati yang ditulis oleh penulis. Dalam bidang karang mengarang, deskripsi dimaksudkan sebagai suatu karangan yang digunakan penulis untuk memindahkan kesan-kesannya, memindahkan hasil pengamatan dan perasaannya, dan disajikan kepada para pembaca. Sasaran yang ingin dicapai oleh penulis deskripsi adalah menciptakan atau memungkinkan terciptanya daya khayal pada para pembaca, sehingga pembaca mengalaminya sendiri.

Model pembelajaran TTW adalah suatu model yang bertumpu kepada pengembangan kemampuan berpikir terhadap suatu masalah yang selanjutnya mengkomunikasikan masalah tersebut melalui diskusi kelompok dan menuliskan hasil yang diperoleh sebagai pemecahan masalah.

Langkah-langkah model TTW yaitu. (1) (think) yaitu tahap dimana siswa melakukan proses berfikir dari suatu teks atau bacaan kemudian menuliskan apa yang ia ketahui dan tidak diketahunya serta langkah-langkah penyelesaian masalahnya. (2) (talk) yaitu tahap dimana siswa dibagi dalam sebuah kelompok kecil dimana siswa melakukan proses komunikasi dan bertukar pendapat dengan siswa lain mengenai masalah atau ide yang diperoleh pada tahap think. (3) (write) yaitu tahap dimana siswa melakukan hasil konstruksi ide yang ia dapat dari tahap talk dalam bentuk tulisan. 
Media audio visual adalah media perantara atau penggunaan materi dan penyerapannya melalui pandangan dan pendengaran sehingga membangun kondisi yang dapat membuat siswa mampu memperoleh pengetahuan, keterampilan, atau sikap.

Model TTW berbantuan media audio visual adalah model pembelajaran yang digunakan dalam proses pembelajaran di kelas yang berfungsi agar siswa dapat memahami materi yang disampaikan oleh guru dan memecahkan masalah agar siswa dapat melatih keterampilan menulis deskripsi.

\section{Metode}

Dalam pelaksanaan penelitian ini terdapat tata cara yang dilakukan dalam mengumpulkan informasi atau data serta melakukan investigasi terhadap data yang telah didapatkan.

Waktu penelitian terkait dengan penelitian ini dilaksanakan mulai bulan Februari 2018 sampai dengan bulan April 2018, dengan memberikan perlakuan sebanyak 6 kali di kelompok eksperimen dan 6 kali di kelompok kontrol. Jumlah perlakuan yang diberikan telah disesuaikan dengan jam pembelajaran terkait materi dalam penelitian ini yang telah diatur dalam kurikulum dan silabus.

Adapun beberapa macam rancangan atau desain penelitian. Pemilihan rancangan sangat ditentukan oleh jenis masalah yang diteliti dan tujuan penelitian. Penelitian ini dilaksanakan pada kelas III SDN Gugus VIII I Gusti Ketut Pudja Kecamatan Denpasar Selatan semester II tahun ajaran 2017/2018. Jenis penelitian yang dilakukan dalam penelitian ini adalah penelitian kuantitatif dengan desain eksperimental yaitu eksperimen semu (quasy eksperimental design). Sugiyono (2016:77) memaparkan bahwa, "Desain eksperimen semu (quasy experimental design) mempunyai kelompok kontrol tetapi tidak dapat berfungsi sepenuhnya untuk mengontrol variabel-variabel luar yang memengaruhi pelaksanaan eksperimen". Hal ini dikarenakan kemampuan peneliti dalam mengamati perilaku siswa terbatas terutama ketika siswa berada di luar sekolah. Bentuk desain eksperimen semu (quasy experimental design) yang digunakan dalam penelitian ini yaitu non-equivalent control group design.

Pada bentuk desain non-equivalent control group design, terdapat dua kelompok sampel yang terdiri dari kelompok eksperimen dan kelompok kontrol sebagai subjek penelitian yang dibandingkan. "Subjek penelitian atau partisipan penelitian tidak dipilih secara acak untuk dilibatkan dalam kelompok eksperimen dan kelompok kontrol" (Setyosari, 2015:210). Dengan demikian, kelompok eksperimen dan kelompok kontrol yang digunakan sudah terbentuk tanpa adanya campur tangan peneliti dan tidak dilakukan random individual karena tidak mungkin mengacak kelas yang sudah terstruktur oleh sekolah. Secara skematis, desain eksperimen semu (quasy experimental design) yang digunakan pada penelitian ini dapat diilustrasikan sebagai berikut.

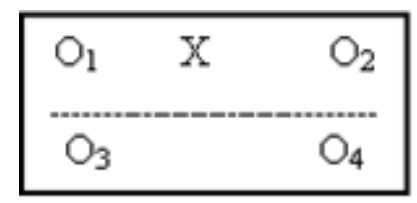

(Sumber: Sugiyono, 2016:79)

\section{Gambar 1. Rancangan Non-equivalent Control Group Design}

Berdasarkan desain eksperimen semu dengan bentuk non-equivalent control group design, maka hanya diperhitungkan skor posttest saja tanpa memperhitungkan skor pretest karena tujuan dilakukan penelitian ini hanya untuk mengetahui pengaruh bukan peningkatan keterampilan menulis deskripsi pada kelompok eksperimen yang diberikan perlakuan model pembelajaran TTW berbantuan media audio visual dan kelompok kontrol yang tidak diberikan perlakuan model pembelajaran TTW berbantuan media audio visual. Pretest diberikan untuk kelompok kontrol dan kelompok eksperimen. Pretest hanya dilakukan sebagai penyetaraan kelompok. Teknik yang digunakan dalam penyetaraan kelompok adalah dengan menggunakan uji-t. Selanjutnya, posttest digunakan untuk mendapatkan data keterampilan menulis deskripsi dari kelompok eksperimen dan kelompok kontrol.

Populasi penelitian ini adalah seluruh siswa kelas III SDN Gugus VIII I Gusti Ketut Pudja Kecamatan Denpasar Selatan yang tersebar di tiga SDN sebanyak 150 siswa. Sampel adalah "sekelompok objek, orang, peristiwa, dan sebagainya yang merupakan representasi dari 
keseluruhan" (Setyosari, 2015:220). Sedangkan menurut Sugiyono (2016:81), "Sampel adalah bagian dari jumlah dan karakteristik yang dimiliki oleh populasi tersebut". Jadi dapat disimpulkan bahwa sampel adalah bagian dari populasi yang mewakili anggota populasi. Dalam pengambilan sampel penelitian ini menggunakan teknik Random Sampling, Sugiyono (2016:91) mengemukakan "karena teknik sampling adalah random, maka setiap anggota populasi mempunyai peluang yang sama untuk dipilih menjadi anggota sampel". Dengan demikian, dalam penelitian ini setiap kelas mendapatkan kesempatan yang sama untuk dijadikan sampel.

Dalam penelitian ini dipilih dua kelas yang digunakan sebagai sampel. Satu kelas sebagai kelompok eksperimen yang diberikan perlakuan dengan menerapkan model pembelajaran TTW berbantuan media audio visual dan satu kelas sebagai kelompok kontrol yang diberikan pembelajaran konvensional. Kedua kelompok diberikan pretest untuk menyetarakan secara akademik. Dalam hal ini pretest digunakan untuk menyetarakan kelompok. Apabila kedua kelompok dinyatakan setara, selanjutnya dilakukan pengundian kembali bagi kedua kelompok tersebut untuk menentukan kelas yang dijadikan kelompok eksperimen dan kelompok kontrol. Kedua kelompok tersebut dijadikan sampel penelitian.

Sebelum uji kesetaraan menggunakan uji-t, maka data hasil pretest diuji prasyarat yaitu uji normalitas dan homogenitasnya. Jika pretest yang diperoleh sudah memenuhi prasyarat uji normalitas dan homogenitas maka dianalisis menggunakan uji-t.

Uji normalitas dilakukan untuk mengetahui sebaran data keterampilan menulis deskripsi siswa masing-masing kelompok berdistribusi normal atau tidak sehingga dapat ditentukan teknik analisis datanya. Dalam penelitian ini untuk menguji normalitas sebaran data menggunakan Chi-Kuadrat. Uji homogenitas dapat dilakukan apabila kelompok data berdistribusi normal. Dalam hal ini, uji homogenitas dilakukan untuk menunjukkan perbedaan pada uji hipotesis benar-benar terjadi bukan akibat adanya perbedaan dalam kelompok, melainkan akibat adanya perbedaan varians antar kelompok. Uji homogenitas varians dihitung menggunakan uji F. Pengujian dilakukan pada taraf signifikansi $5 \%$ dengan derajat kebebasan untuk pembilang $n_{1}-1$ dan derajat kebebasan untuk penyebut $n_{2}-1$. Kriteria pengujian, jika $F_{\text {hitung }} \leq F_{\text {tabel }}$, maka sampel dinyatakan homogen. Sedangkan jika $F_{\text {hitung }}>F_{\text {tabel }}$, maka sampel dinyatakan tidak homogen.

Setelah dilakukan analisis terhadap pretest kompetensi keterampilan menulis deskripsi, maka diperoleh hasil bahwa pretest kompetensi keterampilan menulis deskripsi siswa kelas III SDN Gugus VIII I Gusti Ketut Pudja tahun ajaran 2017/2018 berdistribusi normal dan homogen serta analisis uji-t.

Validitas penelitian terdiri dari dua jenis yaitu validitas internal dan validitas eksternal. Validitas internal adalah salah satu faktor yang dapat mempengaruh hasil penelitian (Setyosari, 2015). Validitas eksternal adalah salah satu faktor yang mempengaruhi hasil penelitian yang bersumber dari luar penelitian tersebut (Setyosari, 2015).

Metode pengumpulan data merupakan cara atau teknik yang dilakukan untuk mengumpulkan data penelitian. Menurut Agung (2014) beberapa jenis metode pengumpulan data dapat dibedakan menjadi dua jenis, yaitu metode tes dan non tes. Tes adalah "alat atau prosedur yang digunakan untuk mengetahui atau mengukur sesuatu dalam suasana, dengan cara dan aturan-aturan yang sudah ditentukan" Arikunto (2016:67). Sedangkan non tes adalah penilaian yang dilakukan tanpa menguji siswa, melainkan dilakukan dengan melakukan pengamatan secara sistematis, melakukan wawancara, menyebarkan angket, dan memeriksa atau meneliti dokumen-dokumen Sudijono (2015).

Metode yang digunakan dalam penelitian ini adalah tes kompetensi keterampilan menulis bahasa Indonesia. Pengumpulan data kompetensi keterampilan menulis bahasa Indonesia dilakukan pada siswa kelas III SDN Gugus VIII I Gusti Ketut Pudja Kecamatan Denpasar Selatan tahun ajaran 2017/2018.

Dalam penelitian ini data yang dianalisis adalah data kompetensi keterampilan menulis deskripsi siswa, untuk mendapatkan data tersebut digunakan tes kompetensi keterampilan menulis deskripsi. "Tes adalah alat atau prosedur yang digunakan untuk mengetahui atau mengukur sesuatu dalam suasana, dengan cara dan aturan-aturan yang sudah ditentukan" (Arikunto, 2016:67). Dalam penelitian ini, jenis tes yang digunakan adalah tes uraian. Arikunto (2016) menyatakan, tes uraian adalah sejenis tes kemajuan jawaban yang bersifat pembahasan atau uraian kata-kata.

Instrumen yang digunakan dalam penelitian ini yaitu melalui validasi instrumen. Validasi instrumen berkaitan dengan ketepatan alat ukur instrumen. Sudijono (2015) mengatakan bahwa, validitas merupakan salah satu ciri yang menandai tes hasil belajar yang baik. Dalam penelitian ini untuk menguji kevalidan instrumen digunakan validitas isi. "Sebuah tes dikatakan 
memiliki validitas isi apabila mengukur tujuan khusus tertentu yang sejajar dengan materi atau isi pelajaran yang diberikan" (Arikunto, 2016:82). Uji validitas isi dalam penelitian ini adalah menyusun soal berdasarkan kisi kisi yang materinya disesuaikan dengan kurikulum dan bahan pembelajaran pada penelitian. Dengan demikian, validasi instrumen yang digunakan dalam penelitian ini adalah validitas isi.

Uji validitas ini dilakukan dengan cara menyesuaikan tes dengan indikator. Uji validitas isi dilakukan dengan membuat kisi-kisi pertanyaan. "Validitas isi ialah derajat dimana sebuah tes evaluasi mengukur cakupan substansi yang ingin diukur" (Sukardi, 2012:32). Sedangkan (Arikunto, 2015:82) mengatakan "validitas isi merupakan tujuan khusus tertentu untuk mengukur sejajar dengan materi atau isi pelajaran yang diberikan". Jadi dapat disimpulkan validitas isi adalah sebuah alat ukur untuk menentukan sejajar atau tidaknya sebuah tes dengan materi atau isi pelajaran.

Data yang terkumpul dalam pelaksanaan penelitian perlu untuk dianalisis. Teknik analisis yang digunakan untuk menganalisis data dalam penelitian ini adalah teknik analisis statistik inferensial digunakan untuk menganalisis data yang dinormalisasi dari hasil pretest dan posttest.

Analisis statistik inferensial adalah suatu cara mengolah data yang dilakukan dengan menerapkan rumus-rumus statistik inferensial untuk menguji hipotesis penelitian yang diajukan dan menarik kesimpulan berdasarkan hasil pengujian hipotesis (Agung, 2014). Dalam hal ini teknik analisis data yang digunakan untuk uji hipotesis menggunakan uji-t. Sebelum uji-t dilakukan, terlebih dahulu harus memenuhi uji prasyarat analisis, yaitu dengan uji normalitas sebaran data dan uji homogenitas varians.

Uji Normalitas dimaksudkan untuk mengetahui apakah sebaran data skor penguasaan keterampilan menulis Bahasa Indonesia siswa masing-masing kelompok berdistribusi normal atau tidak sehingga dapat menentukan teknik analisis datanya. "Statistik parametris itu bekerja berdasarkan asumsi bahwa data setiap variabel yang akan dianalisis berdasarkan distribusi normal" (Sugiyono, 2009:241). Uji Normalitas sebaran data dalam penelitian ini menggunakan Chi-kuadrat.

Uji Homogenitas dilakukan untuk menunjukkan bahwa perbedaan yang terjadi pada uji hipotesis benar-benar terjadi akibat adanya perbedaan varians antar kelompok, bukan sebagai akibat perbedaan dalam kelompok. Uji homogenitas dapat dilakukan apabila kelompok data tersebut berdistribusi normal. Uji homogenitas varians dilakukan dengan uji $\mathrm{F}$.

Adapun hipotesis statistik yang akan diujikan adalah $\mathrm{HO}$ : Tidak terdapat pengaruh model pembelajaran think talk write berbantuan media audio visual terhadap keterampilan menulis siswa kelas III SDN Gugus VIII I Gusti Ketut Pudja Denpasar Selatan tahun ajaran 2017/2018.

Data yang diperoleh sudah memenuhi prasyarat uji normalitas dan homogenitas maka analisis yang digunakan adalah statistik parametrik. Analisis statistik yang digunakan untuk menguji hipotesis penelitian ini adalah uji beda mean (uji-t). Uji hipotesis menggunakan uji-t dapat dihitung dengan polled varians.

\section{Hasil Dan Pembahasan}

Penelitian ini mendeskripsikan hasil penelitian yaitu data keterampilan menulis deskripsi siswa kelas III SDN 5 Panjer sebagai kelompok eksperimen dan SDN 3 Renon sebagai kelompok kontrol. Kelompok eksperimen menggunakan model pembelajaran think talk write berbantuan media audio visual dan kelompok kontrol menggunakan pembelajaran konvensional. Pemaparan hasil penelitian tersebut meliputi data hasil pretest dan posttest.

Hasil pretest digunakan sebagai penyetaraan sampel penelitian dan hasil posttest yang digunakan sebagai instrumen penelitian berupa tes uraian keterampilan menulis deskripsi yang telah di validasi menggunakan rubrik penilaian. Pretest diberikan pada awal penelitian. Sedangkan posttest diberikan pada akhir penelitian setelah 6 kali perlakuan di kelas eksperimen dan 6 kali pembelajaran di kelas kontrol.

Nilai rata-rata (mean) keterampilan menulis deskripsi kelompok eksperimen sebesar 73,32 dengan standar deviasi sebesar 12,35 varians sebesar 152,52 skor minimun 55 dan skor maksimum adalah 90. Untuk lebih jelasnya distribusi frekunsi keterampilan menulis kelompok eksperimen disajikan pada histogram sebagai berikut. 


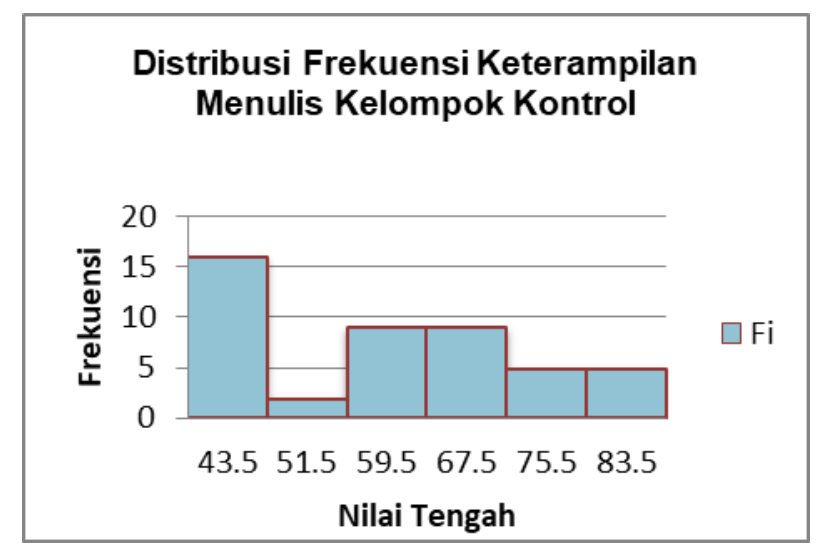

Gambar 2. Histogram Keterampilan Menulis Siswa Kelompok Eksperimen

Berdasarkan gambar histogram keterampilan menulis siswa pada kelompok eksperimen yang terletak di bawah rata-rata sebesar $45 \%$ dan di atas rata-rata $55 \%$.

Nilai rata-rata (mean) keterampilan menulis deskripsi kelompok eksperimen sebesar 59,50 dengan standar deviasi sebesar 14,11 varians sebesar 199,11 skor minimun 40 dan skor maksimum adalah 85 . Untuk lebih jelasnya distribusi frekunsi keterampilan menulis kelompok kontrol disajikan pada histogram sebagai berikut.

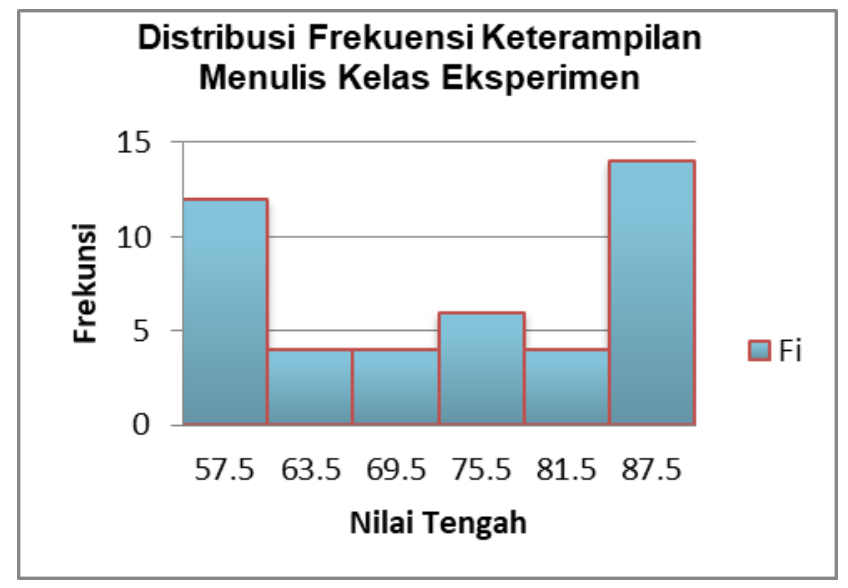

Gambar 3. Histogram Keterampilan Menulis Siswa Kelompok Eksperimen

Berdasarkan gambar histogram keterampilan menulis siswa pada kelompok kontrol yang terletak di bawah rata-rata sebesar $39 \%$ dan di atas rata-rata $61 \%$.

Berdasarkan hasil uji normalitas diketahui data kelompok eksperimen memperoleh $x^{2}$ hitung $=7,83$. Hasil hitung tersebut kemudian dibandingkan dengan $x^{2}$ tabel $=11,07$. Karena $x^{2}$ hitung $<x^{2}$ tabel maka data keterampilan menulis deskripsi kelompok eksperimen dinyatakan berdistribusi normal. Sedangkan hasil uji normalitas data kelompok kontrol diperoleh $x^{2}$ hitung $=$ 9,68 . Hasil hitung tersebut kemudian dibandingkan dengan $x^{2}$ tabel $=11,07$. Karena $x^{2}$ hitung $<$ $x^{2}$ tabel maka data keterampilan menulis deskripsi kelompok kontrol dinyatakan berdistribusi normal.

Diketahui hasil uji homogenitas varian data keterampilan menulis deskripsi memperoleh $F_{\text {hitung }}=1,31$. Hasil hitung tersebut dibandingkan dengan $F_{\text {tabel }}=1,69$. Karena $F_{\text {hitung }}<F_{\text {tabel }}$, maka varian data kelompok eksperimen dan kelompok kontrol dinyatakan homogen.

Hipotesis penelitian yang diuji yaitu tidak terdapat pengaruh model pembelajaran think talk write berbantuan media audio visual terhadap keterampilan menulis siswa kelas III SDN Gugus VIII I Gusti Ketut Pudja Denpasar Selatan Tahun Ajaran 2017/2018.

Berdasarkan uji hipotesis diperoleh $t_{\text {hitung }}=5,025$ pada taraf signifikansi $5 \%$ dengan $\mathrm{dk}=$ 88 diperoleh nilai $t_{\text {tabel }}=2,000$ maka $t_{\text {hitung }}=5,025>t_{\text {tabel }}=2,000$ dan nilai rerata siswa kelompok eksperimen $(\bar{X}=73,32)$ dan kelompok kontrol $(\bar{X}=59,50)$, hipotesis nol $\left(\mathrm{H}_{0}\right.$ 
ditolak) dengan demikian terdapat pengaruh keterampilan menulis siswa yang dibelajarkan melalui model pembelajaran TTW berbantuan media audio visual dengan kelompok siswa yang dibelajarkan melalui pembelajaran konvensional pada kelas III SDN Gugus VIII I Gusti Ketut Pudja Denpasar Selatan.

Berdasarkan perolehan keterampilan menulis deskripsi pada kedua kelompok dapat diketahui bahwa antara kelompok eksperimen dan kelompok kontrol pada mulanya memiliki kemampuan yang setara, kemudian setelah diberikan perlakuan yang berbeda perolehan keterampilan menulis deskripsi mengalami perbedaan. Perbedaan tersebut disebabkan karena pembelajaran yang diterapkan pada kelompok eksperimen memiliki kelebihan dibandingkan pembelajaran yang diterapkan pada kelompok kontrol yaitu pada kelompok eksperimen menggunakan model pembelajaran TTW berbantuan media audio visual sedangkan pada kelompok kontrol menggunakan pembelajaran konvensional.

Dengan menerapkan model pembelajaran TTW siswa terlatih dalam kegiatan berpikir, berbicara, membantu siswa dalam mengkonstruksi pengetahuannya sendiri sehingga pemahaman konsep siswa menjadi lebih baik, mengungkapkan ide dan berbagi ide dengan temannya, siswa mengkomunikasikan atau mendiskusikan pemikirannya sehingga siswa saling membantu dan saling bertukar pikiran. Hal ini akan membantu siswa dalam memahami materi yang diajarkan, melatih siswa untuk menuliskan hasil diskusinya ke bentuk tulisan secara sistematis sehingga siswa akan lebih memahami materi dan membantu siswa untuk mengkomunikasikan pemikiran dalam menciptakan ide, dan menulis hasil pemikiranya tersebut dalam sebuah karangan deskripsi dalam proses pembelajaran.

Didukung oleh Shoimin (2014) yang menyatakan, model pembelajaran TTW merupakan model pembelajaran untuk melatih keterampilan peserta didik dalam menulis. Proses pembelajaran khususnya menulis deskripsi perlu adanya media yang mendukung yaitu dengan menggunakan media audio visual. Media audio visual adalah media perantara atau penggunaan materi dan penyerapannya melalui pandangan dan pendengaran sehingga membangun kondisi yang dapat membuat siswa mampu memperoleh pengetahuan, keterampilan, atau sikap. Model pembelajaran TTW berbantuan media audio visual dalam proses pembelajaran di kelas yang berfungsi siswa memahami materi yang disampaikan oleh guru dan memecahkan masalah agar siswa dapat melatih keterampilan menulis deskripsi. Model pembelajaran TTW berbantuan media audio visual mampu meningkatkan keaktifan siswa dalam proses pembelajaran, membangkitkan semangat siswa dalam mengikuti pembelajaran dan saat proses pembelajaran di kelas berfungsi agar siswa dapat memahami materi yang disampaikan oleh guru. Selama kegiatan pembelajaran siswa lebih aktif karena kegiatan pembelajaran menggunakan model TTW berbantuan media audio visual yang dapat menciptakan suasana belajar yang menyenangkan dengan cara melibatkan siswa dalam interaksi terhadap suasana belajarnya. Pembelajaran yang menyenangkan dikemas dalam kegiatan pembelajaran yang meliputi petunjuk, strategi, dan seluruh proses belajar yang dapat mempertajam daya ingat, serta membuat belajar sebagai suatu proses yang menyenangkan, bermanfaat, dan bermakna. Keaktifan dan semangat siswa dibentuk dengan memberikan dorongan yaitu memperlihatkan media audio visual di dalam proses pembelajaran dapat melatih kemampuan berfikir siswa dalam membuat sebuah karangan deskripsi. Dengan demikian, siswa lebih memahami materi yang diberikan sekaligus mampu mengaplikasikan dalam kehidupan sehari - hari.

Hasil temuan pada penelitian ini memiliki persamaan dengan penelitian sebelumnya yang relevan dan memperkuat hasil penelitian yang diperoleh. Hal tersebut didukung hasil penelitian yang dilakukan oleh Darmawan (2013), persamaan penelitian ini yaitu menggunakan model pembelajaran think talk write. Sedangkan perbedaan pada penelitian ini yaitu tidak menggunakan media dalam proses pembelajaran dan dilakukan pada kelas V. Dengan demikian hasil analisis data diperoleh bahwa $t_{\text {hitung }} 12,46>t_{\text {tabel }} 2,000$ dan nilai rata-rata 86,3 pada kelas eksperimen sedangkan pada kelas kontrol memperoleh rata-rata 58,87 . Sehingga dapat disimpulkan bahwa model pembelajaran think talk write berpengaruh terhadap keterampilan menulis deskripsi siswa kelas V di Gugus III Kecamatan Tejakula Kabupaten Buleleng tahun pelajaran 2016/2017. Serta penelitian oleh Fatkasari (2017) yaitu memiliki persamaan penelitian dengan menggunakan model pembelajaran think talk write. Sedangkan perbedaan pada penelitian ini yaitu tidak menggunakan media dan dilakukan pada kelas IV. Dengan demikian hasil analisis data diperoleh bahwa $t_{\text {hitung }} 3,575>t_{\text {tabel }} 2,000$. Sehingga dapat disimpulkan bahwa model pembelajaran think talk write berpengaruh terhadap keterampilan menulis deskripsi siswa kelas IV SDN Petusari 3 Kecamatan Pandaan Kabupaten Pasuruan. 
Dengan demikian, pembelajaran menggunakan model pembelajaran TTW berbantuan media audio visual pada penelitian ini memiliki keunggulan yakni dapat membuat siswa lebih aktif dalam pembelajaran dan meningkatkan kemampuan berpikir siswa dengan memberikan pengalaman yang berkesan bagi siswa berdasarkan pada komponen pengalaman belajar, didukung oleh peranan guru dalam pemberian materi yang disampaikan.

\section{Simpulan dan Saran}

Berdasarkan hasil analisis dapat diperoleh yaitu terdapat pengaruh yang signifikan model pembelajaran TTW berbantuan media audio visual terhadap keterampilan menulis deskripsi siswa kelas III SDN Gugus VIII I Gusti Ketut Pudja tahun ajaran 2017/2018. Hasil analisis data diperoleh $t_{\text {hitung }}=5,025$ dengan taraf signifikan $5 \% d k=88$ diperoleh $t_{\text {tabel }}=2,000$. Berarti $t_{\text {hitung }}>$ $t_{\text {tabel }}$ yaitu 5,025 > 2,000, maka $\mathrm{H}_{0}$ yang diajukan ditolak dan $\mathrm{H}_{\mathrm{a}}$ diterima. Sehingga dapat disimpulkan bahwa terdapat pengaruh model pembelajaran TTW berbantuan media audio visual terhadap keterampilan menulis deskripsi siswa kelas III SDN Gugus VIII I Gusti Ketut Pudja tahun ajaran 2017/2018.

Adapun saran yang disampaikan kepada guru, agar lebih kreatif untuk memberikan variasi dalam pembelajaran. Fasilitas berupa sumber belajar dan kesempatan yang lebih besar bagi siswa pada pembelajaran dengan menggunakan model pembelajaran TTW berbantuan media lingkungan sehingga tercipta pembelajaran bermakna dan menyenangkan bagi siswa. Kepada sekolah, agar dapat menggunakan hasil penelitian ini sebagai pendukung sumber belajar guru dalam meningkatkan kualitas pembelajaran dengan menciptakan variasi pembelajaran yang menyenangkan di sekolah sehingga sekolah mampu menghasilkan siswa yang berkualitas. Kepada peneliti lain, agar hasil penelitian ini digunakan sebagai referensi untuk melaksanakan penelitian selanjutnya atau menemukan inovasi kegiatan pembelajaran lainnya yang bermakna dan menyenangkan bagi siswa.

\section{Daftar Pustaka}

Agung, A. A. Gede. 2014. Metodologi Penelitian Pendidikan. Singaraja: FIP Undiksha.

Arikunto, Suharsimi. 2015. Dasar-Dasar Evaluasi Pendidikan. Jakarta: PT Bumi Aksara.

Asyhar, H. Rayandra. 2012. Kreatif Mengembangkan Media Pembelajaran. Jakarta: Referensi Jakarta.

Asmarine (2016). Peningkatan Keterampilan Menulis Karangan Deskripsi Melalui Model Pembelajaran Menulis Think-Talk-Write (Ttw) Dengan Media Visual Pada Siswa Kelas Iv Sdn Inpres 3 Talise . Jurnal Bahasantodea, Volume 4 Nomor 2, April 2016

Darmawan, Km. Agus. 2017. "Pengaruh Model Pembelajaran Think Talk Write Terhadap Keterampilan Menulis Deskripsi Siswa Kelas V". E-Journal PGSD Universitas Pendidikan Ganesha, Volume 5, No. 2 (diakses tanggal 18 Januari 2018).

Fatkasari, Dyah. 2017. "Pengaruh Model Pembelajaran Kooperatif Tipe Think Talk Write Terhadap Keterampilan Menulis Deskripsi Siswa Kelas IV Sdn Petung Asri 3 Kecamatan Pandaan Kabupaten Pasuruan" Jurusan Pendidikan Guru Sekolah Dasar FIP Universitas Negeri Surabaya, Volume 5, Nomor 3.

Hasabullah. 2008. Dasar-Dasar Ilmu Pendidikan. Jakarta: PT RajaGafindoPersada.

Huda, Miftahul. 2013. Model-Model Pengajaran Dan Pembelajaran. Yogyakarta: PUSTAKA PELAJAR.

Permata ,Intan (2017). Pengaruh Model Pembelajaran Kooperatif Tipe Think-Talk-Write Terhadap Keterampilan Menulis Argumentasi Siswa Pada Materi Ekosistem . Jurnal Pendidikan Bilogi, Tahun 2017 
Ratna ,Setya (2017). Keefektifan Model Pembelajaran Think Talk Write (Ttw) Terhadap Kemampuan Menulis Cerita Ditinjau Dari Minat Menulis Pada Siswa Kelas Iv Sekolah Dasar . PGSD FKIP Universitas Sebelas Maret ISSN : 2337 - 8786

Setyosari, Punaji. 2015. Metode Penelitian Pendidikan\&Pengembangan. Jakarta: Prenadamedia Group.

Shoimin, Aris. 2014. 68 Model Pembelajaran Inovatif dalam Kurikulum 2013. Yoyakarta: ARRUZZ MEDIA.

Sudijono, Anas. 2013. Pengantar Evaluasi Pendidikan. Jakarta: PT Raja Grafindo Persada.

Sugiarti, Ni Luh Pt. Yeni. 2014. "Pengaruh Model Pembelajaran TTW (Think Talk Write) Berbantuan Media Gambar Berseri Terhadap Keterampilan Menulis Bahasa Indonesia Siswa Kelas V SD Gugus 1 Kecamatan Kediri Tahun Ajaran 2013/2014". Jurnal Pendidikan dan Pengajaran, Volume 2, Edisi Januari (diakses tanggal 18 Januari 2018).

Sugiyono. 2016. Metode Penelitian Administrasi. Jakarta: Alfabeta: Bandung.

Sugiyono. 2016. Metode Penelitian Kuantitatif, Kualitatif, dan R\&D. Bandung: Alfa Beta.

Sukardi. 2016. Metodologi Penelitian Pendidikan Kompetensi dan Praktiknya. Jakarta: PT Bumi Aksara. .

Susanto, Ahmad. 2013. Teori Belajar Dan Pembelajaran Di Sekolah Dasar. Jakarta: Prenadamedia Group.

Tarigan, Henry Guntur. 2013. Menulis Sebagai Suatu Keterampilan Berbahasa. Bandung: Angkasa.

Yanuarta ,Lidya (2014). Penerapan Model Pembelajaran Kooperatif Tipe Think, Talk, Write (Ttw) Dengan Teknik Talking Stick Dalam Meningkatkan Karakter Dan Hasil Belajar IpaBiologi (Siswa Kelas Vii-E Smp Negeri 2 Kalisat Semester Genap Tahun Ajaran 2012/2013) . Jurnal Pancaran, Vol. 3, No. 3, hal 69-78, Agustus 2014 